\title{
3D プリント連続炭素繊維強化熱可塑複合材料の引張試験特性
}

\author{
轟章*1, 大浅田 樹*2, 水谷 義弘*3, 鈴木 良郎*3 \\ 上田 政人*4, 松崎 亮介*5, 平野 義鎭*6 \\ (2019 年 3 月 18 日受付)
}

\author{
Tensile-test-Property Evaluations of 3D Printed Continuous Carbon Fiber \\ Reinforced Thermoplastic Composites
}
Akira Todoroki, ${ }^{* 1}$ Tatsuki OASAdA, ${ }^{* 2}$ Yoshihiro Mizutani, ${ }^{* 3}$ Yoshiro Suzuki, ${ }^{* 3}$ Masahito Ueda, ${ }^{* 4}$ Ryosuke MatsuzAKI ${ }^{* 5}$ and Yoshiyasu Hirano*6

(Received March 18, 2019)

\begin{abstract}
Continuous carbon fiber composites can be printed with 3D printers. Many studies detailing elucidations of the mechanical properties of such $3 \mathrm{D}$ printed composites have been published, all of which employed a conventional tensile specimen configuration with surface resin layers. In the present study, $0^{\circ}, 90^{\circ}, \pm 45^{\circ}$, and lay-up direction type specimens were newly designed for 3D printed composites without surface layers. Using the 3D printer, both conventional and newly designed specimens with serpentine folded fiber bundles were fabricated and investigated experimentally. The lay-up direction specimen was fabricated using 800 layers. The specimens without the serpentine folded fiber bundles were experimentally shown to be adequate for tensile tests. The lay-up direction specimen had the lowest strength and stiffness, which seems to be related to its surface roughness.
\end{abstract}

Key words: Tensile strength, Shear strength, 3D printed composites, Carbon fiber

\section{1. 緒言}

熱溶融積層 (FDM) 方式の 3D プリンタを用いて，連 続した炭素繊維を含有した熱可塑性樹脂の複合材料構造 が成形可能になった ${ }^{1,2)}$.この $3 \mathrm{D}$ プリント複合材料では, 複雑な形状が容易に成形できる利点を有している。長繊 維で強化された熱可塑性樹脂は，金属に近い強度を有し
ており，金属の 3D プリンタに比較して大幅に安価とな る. Koga らは凹凹のある表面形状を 3D プリンタで成 形し, せん断強度を向上させた新継手を考案している3). このような $3 \mathrm{D}$ プリンタの特性を活用した複雑形状の製 品が今後期待されている.しかし，これらの設計に必要 な基礎的機械特性を測定するための試験片作製にも複数 の方式が考えられる。例えば, MarkForged 社の Mark-

*1 東京工業大学工学院 教授 (152-8550 東京都目黒区大岡山 2-12-1)

Tokyo Institute of Technology, School of Engineering, 2-12-1, Oookayama, Meguro, Tokyo 152-8550, Japan

*2 東京工業大学 修士

Graduate Student, Tokyo Institute of Technology

*3 東京工業大学

Tokyo Institute of Technology

*4 日本大学理工学部 准教授

Associate Professor, Nihon University

*5 東京理科大学理工学部 准教授

Associate Professor, Tokyo University of Science

*6 JAXA 航空技術部門 主任研究員

Associate Senior Researcher, Japan Aerospace Exploration Agency (JAXA) 
Two を用いて䋊維方向の引張特性を求める試験片を作 製する場合でも，表面樹脂層の扱いや繊維折れ曲がり繊 維束の扱いに複数の方法が選択可能であり, 実験的に詳 細な検討が必要である. 長䋊維を用いた多くの研究で は，従来のプリプレグシートを積層する成形手法とほぼ 同様の繊維束の状態になるように成形して引張試験を実 施している ${ }^{4 \sim 8)}$. 䋊維束を屈曲させることが可能な $3 \mathrm{D}$ プ リント複合材料では, 繊維束屈曲の影響を評価する必要 があり，基礎的な検討が開始されたばかりであるのが現 状である ${ }^{9,10)}$.

本研究では引張試験に限定し，様々な繊維方位の引張 試験片の 3D プリント成形を検討して, 機械的強度や弾 性係数を測定している. 従来のプリプレグを用いたオー トクレーブ成形では困難であった積層方向の引張試験も 実施している。

\section{FDM 方式の複合材料 $3 \mathrm{D}$ プリンタの概要}

MarkForged 社の MarkTwo の模式図を Fig. 1 に示 す. MarkTwo では，ナイロンフィラメントを印刷する 系と, FRP フィラメントを印刷する系の 2 ヘッドを備え ている.ナイロンのフィラメントは通常の $1.75 \mathrm{~mm}$ 径で あり，ノズルは通常の 3D プリンタで使用される $0.4 \mathrm{~mm}$ 径を使用している (Fig. 2 参照)。炭素繊維/ナイロンの CFRTP やガラス/ナイロンの GFRP などの複合材フィ ラメントを印刷するノズルは，ナイロン樹脂ノズルと別 に存在する。ただし, 複合材ノズルは一つであり, CFRP と GFRPでフィラメントを交換して印刷する必要があ る. CFRTP のフィラメント径は $0.4 \mathrm{~mm}$ である. FRP のノズルは，縁がなだらかになっている。これは印刷時 にノズル端部でのアブレーション繊維破断を避けるため と思われる。またノズルヘッドでCFRTPを押しつけ て, 繊維束を平坦化する機能も有している。押しつぶさ れた後のCFRTP 層の厚さは $0.125 \mathrm{~mm}$ の程度である. $0^{\circ}$ の引張と圧縮の機械的特性值は MarkForged 社 Web サイトに揭載されている ${ }^{11)}$. 引張強度は $800 \mathrm{MPa}$, 引張 弾性係数は $60 \mathrm{GPa}$ である.フィラメントの炭素繊維の 体積含有率は約 $30 \%$ である4).

MarkTwo では, CFRTP フィラメントだけを用いて 印刷することができない. 印刷ベッドに最初に表面ナイ ロン層を作製し，その上にCFRTP フィラメントを置い ていく.これは CFRTP フィラメントのベッドとの接着 性の悪さを補うための手段であり，特別な処理無しでは 避けることができない.このため, 表面ナイロン層厚さ の設定で試験片全体の繊維体積含有率が変化し, 引張強

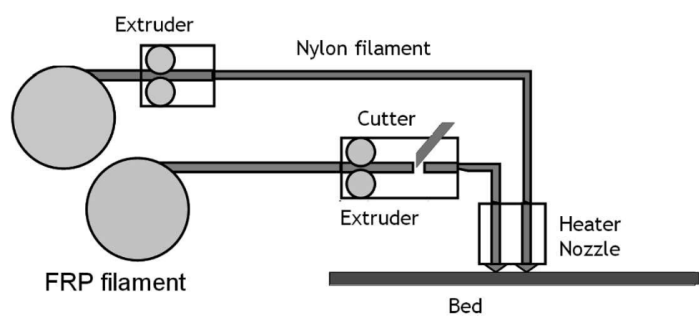

Fig. 1 Schematic representation of MarkTwo printer system.

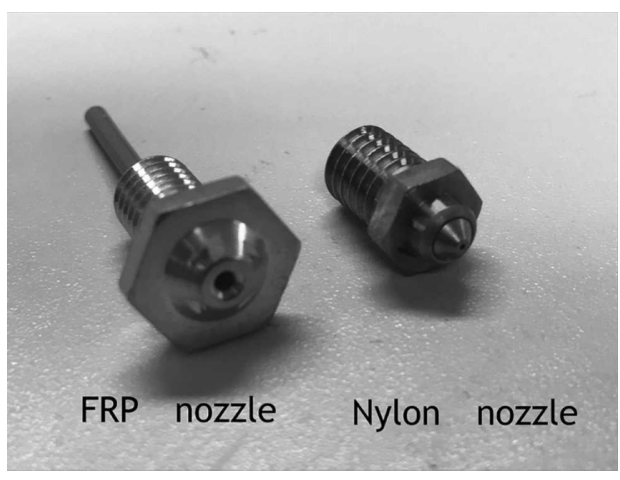

Fig. 2 Printer nozzles used for MarkTwo.

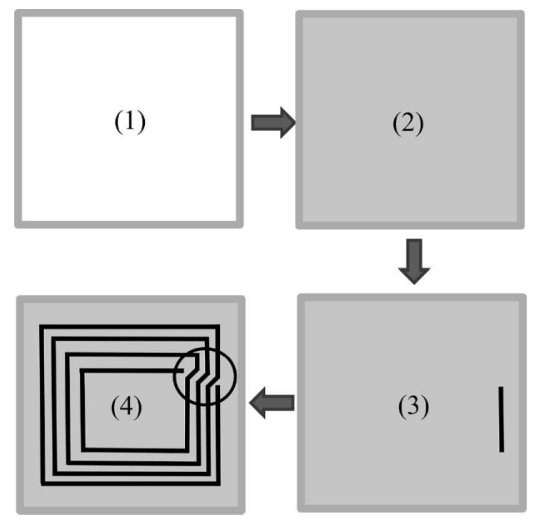

Fig. 3 Print process of MarkTwo.

度も変化する ${ }^{4)}$. 繊維配置は MarkForged 社の提供する Eiger というスライスソフトで自動的に決定される。た だし，繊維配向は面内で渦巻き状になる（蛇行した折り 曲げ形式も可能).

Fig. 3 に成形プロセスを示す。最初(1)壁となる部分 がナイロンで印刷される。次に(2)表面となる部分がナ イロンで印刷される. (3) 次に FRPヘッドから繊維強化 フィラメントがナイロンの表面の上に印刷される. 印刷 は (4)に示すような渦巻き状である. 渦巻き状の繊維束 


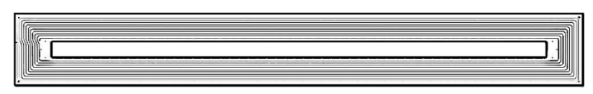

(a) Fiber bundle placement on Eiger

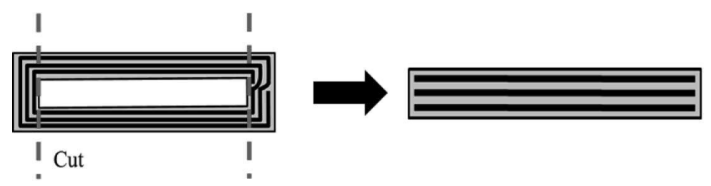

(b) Specimen fabrication process

Fig. 4 Print process of $0^{\circ}$ specimens.

では角部には繊維束の急激な折れ曲がり箇所が発生す る.また，らせんになるために繊維束が横にずれる折れ 曲がり箇所が発生する (Fig. 3 の○印部分).

\section{3. 試験片作製方法と実験方法}

\section{1 試験片の作製}

\subsection{1 $0^{\circ}$ 引張試験片作製手法}

文献)では，表面樹脂層をそのまま用いて繊維方位の 引張試験を実施している。本研究では, CFRTP フィラ メントだけで作製した素材強度を求めるため, 表面のナ イロン層を除去している．しかし，表面樹脂層なしでは CFRTP 層は $3 \mathrm{D}$ プリンタで成形できない. この研究で は, 試験片印刷時のサイズょりも $50 \%$ 程度大きめなナイ ロン層をベッドに成形し，これをCFRTP 層の融着に使 用する。この状態で $3 \mathrm{D}$ プリンタを停止させ，ナイロン フィラメントを外し, 試験片形状を印刷する. 最後にへ ラを用いてベッドのナイロン層から CFRTP で印刷し た試験片を剝がす。こうすることで側面の壁層と表面ナ イロン層の無いCFRTP だけの試験片が作製できる.

Fig. 4 に $0^{\circ}$ 引張試験片の印刷パターンを示す. 中央が 空洞な長方形を印刷することで，1回の印刷で 2 本の試 験片が作製可能である。これは文献) に示されている形 状と同じである。文献)では MarkForged 社の MarkOne を用いている. Eigerソフトのバージョンが古く, CFRTP の印刷開始点 (Fig. 3 ○印) の位置指定ができな かった。このため, 引張試験片のゲージ長部分に印刷開 始点が来ると, 大きな欠陥となって, ばらつきの原因と なった. MarkTwo では引張試験のゲージ部から離れた 切り捨て部に渦巻き繊維の繊維束がずれる場所を設置し ている (Fig. 3 参照)。この部分は引張試験時前に切断除 去されるため, CFRTP 束の横ずれの影響は無い.

$0^{\circ}$ 引張試験は通常の短冊型試験片 (Fig. 4 参照) で, 長 さ $200 \mathrm{~mm}$ ，幅 $12.5 \mathrm{~mm}$ ，厚さ $1 \mathrm{~mm}$ である．厚さ方向 には 8 層のCFRTP 層を積層している。両端 $50 \mathrm{~mm}$ 部

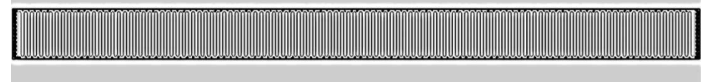

(a) Fiber bundle placement on Eiger

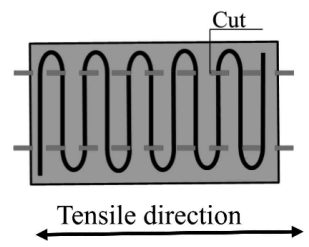

(b) Specimen fabrication process

Fig. 5 Print process of $90^{\circ}$ specimens.

分には厚さ $1.5 \mathrm{~mm}$ の織物 GFRP 製タブを接着して試 験を実施している. 試験片中央部分には 2 軸ひずみゲー ジを貼り付けて，引張方位と直交方位のひずみを測定し た.

\section{$3.1 .290^{\circ}$ 試験片作製手法}

$0^{\circ}$ 試験片と同様の方法で表面層の無い試験片を成形 した。試験片寸法は長さ $200 \mathrm{~mm}$, 幅 $15 \mathrm{~mm}$, 厚さ $2 \mathrm{~mm}$ である。厚さ方向には 16 層の CFRTP 層を積層してい る。両端タブ部は $0^{\circ}$ 引張試験片と同じである.

$90^{\circ}$ 試験片では, Fig. 5 に示すように端部で繊維束の 折り返しを生じる. 文献8)では, ガラス繊維の $90^{\circ}$ 試験 片に折り返しを含む形状を用いている.しかし, 折り返 しの有無の影響は考慮されていない. $90^{\circ}$ 試験片の適正 を確認するために，この折り返し部分を含む試験片と Fig. 5 に示すように両端を切り落として折り返し部分を 含まない試験片の 2 種類を作製した. 折り返し部分を含 まない試験片は両端 $5 \mathrm{~mm}$ ずつを切断した後の板幅を $15 \mathrm{~mm}$ にするため, 成形時の板幅寸法は $25 \mathrm{~mm}$ とした。 このために 2 種類の引張試験時の試験片幅寸法は同一で ある。

\section{1. $3 \pm 45^{\circ}$ 引張試験作製手法}

$0^{\circ}$ 試験片と同様の方法で表面層の無い試験片を成形 した。この試験は JISK7019-1999 の面内せん断特性試験 である．試験片寸法は長さ $250 \mathrm{~mm}$ ，幅 $25 \mathrm{~mm}$ ，厚さ $1.875 \mathrm{~mm}$ である. 厚さ方向には 15 層の CFRTP 層を積 層している. MarkForged の繊維配置を実施するスライ スソフト Eigerでは, 繊維方位の対称積層は指定できな い.このため, 奇数層の積層とすることで対称積層 $\left[(45 /-45)_{7} / 45\right]_{\mathrm{s}}$ としている.ただし, 下線部の $45^{\circ}$ 層は 中央層である (Fig. 6). 


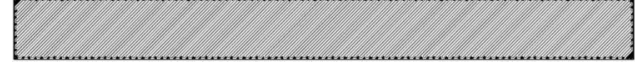

(a) Fiber bundle placement on Eiger

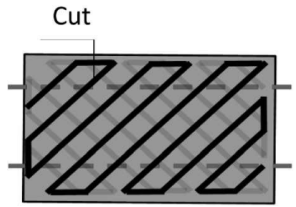

Tensile direction

(b) Specimen fabrication process

Fig. 6 Print process of $\pm 45^{\circ}$ specimens.

\section{1 .4 積層方向試験片}

$0^{\circ}$ 試験片と同様の方法で表面層の無い試験片を成形 した。試験片寸法は長さ $100 \mathrm{~mm}$ (積層方向), 幅 $30 \mathrm{~mm}$, 厚さ $3 \mathrm{~mm}$ である. 試験片厚さ方向には 24 層の CFRTP 層を並べている。積層方向の試験片は，当初はFig. 7 に 断面を示すように試験片内で印刷開始点と終了点を含 み，折り返しも存在する Type A (Fig. 7) を検討した. しかし, 実際には印刷開始点が正しく成形できないため に欠陥となってしまい（位置ずれの発生), Type A は断 念した。そこで，Fig. 8 亿示すように中央に正方形の穴 のある正方形を印刷し，印刷開始点と終了点を試験片か ら除外することにした．積層方向は 800 層の積層を実施 して，高さ $100 \mathrm{~mm}$ の試験片を作製している.

\section{2 引張試験方法}

成形した試験片を引張試験機に取り付け, 引張試験を 行った. 引張速度は $0^{\circ}$ 方向, $90^{\circ}$ 方向および士 $45^{\circ}$ 方向の 引張試験片で $1 \mathrm{~mm} / \mathrm{min}$, 積層方向引張試験片は長さが 半分であるために $0.5 \mathrm{~mm} / \mathrm{min}$ としてひずみ速度をほほ 一定となるようにした．また，試験片中央に二軸のひず みゲージを取り付け，縦ひずみおよび横ひずみを測定し た. 引張弾性係数は, 引張応力-ひずみ曲線に扔ける初期 の直線部分（ひずみが $0.05 〜 0.25 \%$ ）を用いて算出した. ポアソン比は実測した縦ひずみと横ひずみの比の逆符号 から算出した。 $\pm 45^{\circ}$ 方向の引張試験片に抢いては, JISK7079 に基づいて，せん断応力一せん断ひずみ関係を 測定し, せん断弹性係数を求めた。 せん断弾性係数は, 他の試験と同様に初期のほぼ直線とみなせる部分（ひず み範囲：0.05〜0.25\%）を用いている.

なお，JIS K7075-1991 の燃焼法を用いてそれぞれの試 験片の繊維体積含有率とボイド率も測定した。繊維の体 積含有率は全ての試験片で文献) とほぼ同じ $30 \%$ 程度

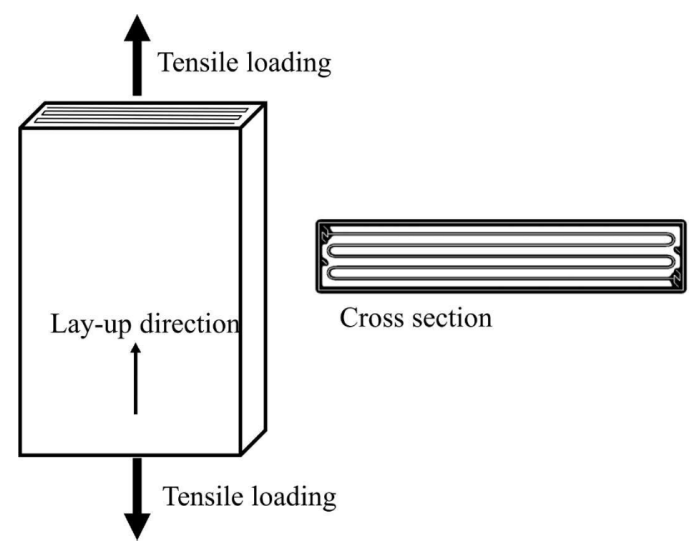

Fig. 7 Print process of lay-up direction specimens (Type A).

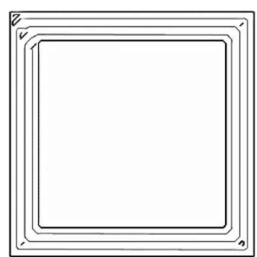

(a) Fiber bundle placement on Eiger

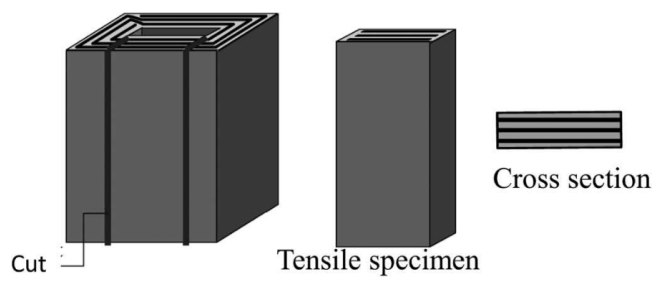

(b) Specimen fabrication process

Fig. 8 Print process of lay-up direction specimens (Type B).

であった。ただし，繊維を $\mathrm{T} 300$ として計算した值であ り，他社纎維の場合には誤差がある。

\section{4. 実験結果と考察}

\section{$4.10^{\circ}$ 引張試験}

$0^{\circ}$ 引張試験の結果を Fig. 9 亿示す. 文献) と比較して ばらつきは小さい.これは Fig. 3 の○印で示す繊維束の 急激な折机曲がり箇所が試験片内に無いこと, 繊維束の 印刷開始位置がゲージ長さ範囲に無いことがあげられ る.破断部のマクロ写真を Fig. 10 亿示す.繊維の体積含 有率が少なく，ナイロン樹脂の延性が大きいために，ほ うき状ではなく，縦割れを含む荷重方位にほぼ垂直な断 


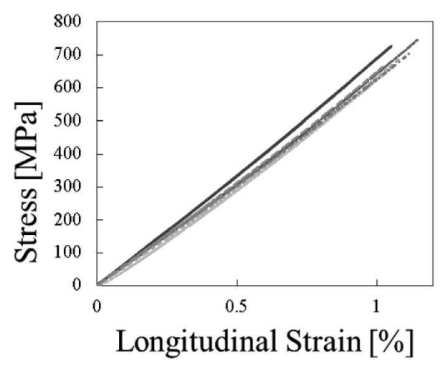

Fig. 9 Stress-strain curve of $0^{\circ}$ specimen.

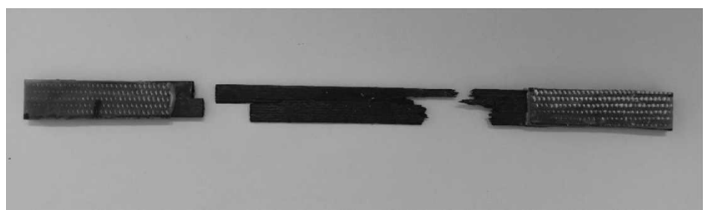

Fig. 10 Typical fractured $0^{\circ}$ specimen.

Table 1 Measured results of tensile tests.

\begin{tabular}{lcccc}
\hline \hline & $0^{\circ}$ & $90^{\circ}$ & $\begin{array}{c} \pm 45^{\circ} \\
\text { (shear) }\end{array}$ & $\begin{array}{c}\text { Lay-up } \\
\text { direction }\end{array}$ \\
\hline Strength [MPa] & 701 & 19.0 & $90.4^{*}$ & 5.07 \\
Elastic modulus [GPa] & 60.9 & 3.97 & 2.27 & 2.40 \\
Poisson's ratio & 0.42 & 0.066 & & \\
\hline
\end{tabular}

${ }^{*}$ Without considering the effect of fiber rotation

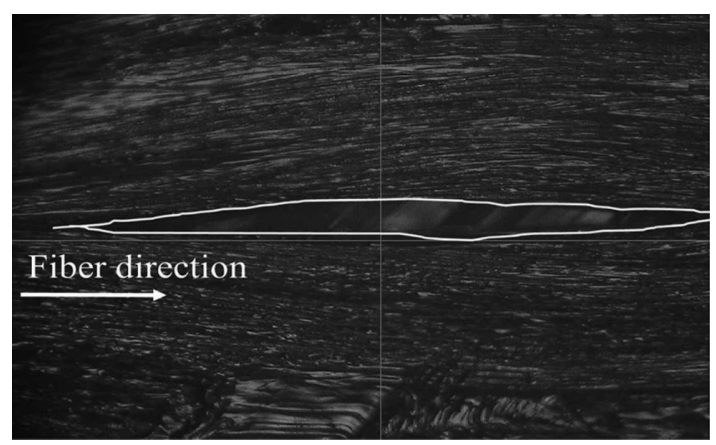

Fig. 11 Fiber bundle curve of $0^{\circ}$ specimen.

面で破壊している．引張試験結果を Table 1 に示す。文 献) にあるように, T300クラスの炭素瀻維が体積含有率 $30 \%$ で含有されていることがわかる。 な扔，大きな引張 ひずみ負荷で傾きがわずかに増加している。これは，3D プリント複合材料の連続繊維束が湾曲しているためであ る (Fig. 11 参照)。湾曲した絨維束が引張負荷によって 湾曲が修正される引張方向に延ばされることが原因であ る. $3 \mathrm{D}$ プリンタでは，様及な方位にヘッドを動かすと フィラメントがねじられる。このため, フィラメント中

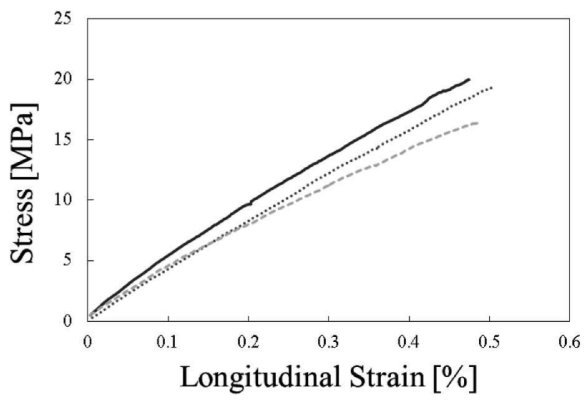

Fig. 12 Stress-strain curve of $90^{\circ}$ specimen.

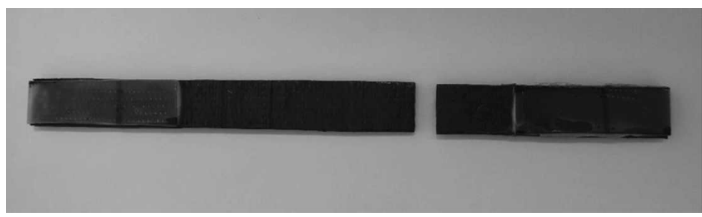

Fig. 13 Typical fractured $90^{\circ}$ specimen.

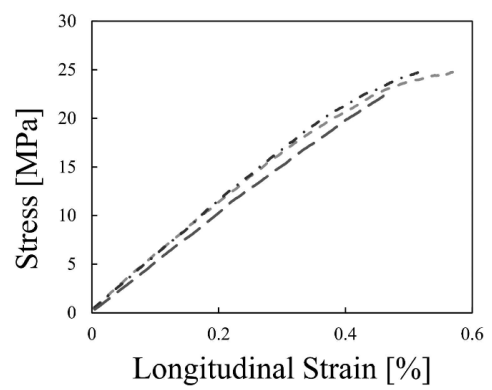

Fig. 14 Stress-strain curve of $90^{\circ}$ specimen with folded fiber bundles.

の炭素繊維のねじれが生じる。そして, 成形時に繊維束 の局所的湾曲が発生している.

\section{$4.290^{\circ}$ 引張試験}

$90^{\circ}$ 引張試験の結果を Fig. 12 亿示す. $90^{\circ}$ 引張試験の ばらつきはやや大きい.およそ $0.3 \%$ 程度のひずみから 塑性変形が開始していることがわかる.しかし, 大きな 塑性変形は無く, 破断に至っている. 引張試験の測定結 果を Table 1 に示す. 引張破断の様相を Fig. 13 に示す. 繊維の折り返し部分を含む場合の引張試験結果を Fig. 14 に示す. 破断強度が上昇しており, 最大荷重付近では 応力ーひずみ関係に大きな非線形性が認められる。また， 弾性係数も $4.95 \mathrm{GPa}$ であり, 折り返しの無い試験片の 值（3.97 GPa）よりも大きくなった。これは，折り返し 部分に $0^{\circ}$ 方向の炭素瀻維が存在していることが原因で あると考えられる。このため, $3 \mathrm{D}$ プリント複合材の $90^{\circ}$ 


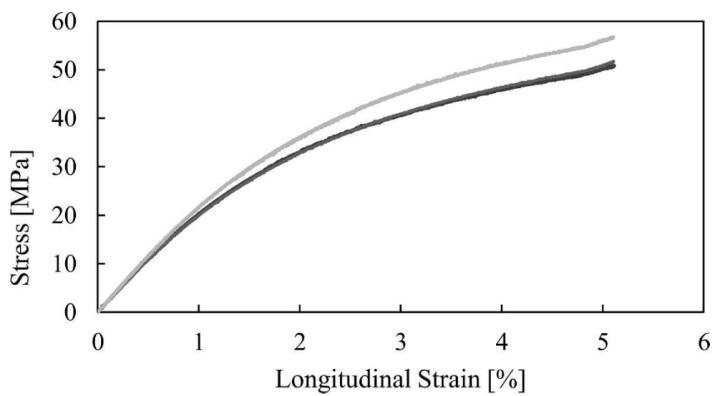

Fig. 15 Stress-strain curve of $\pm 45^{\circ}$ specimen.

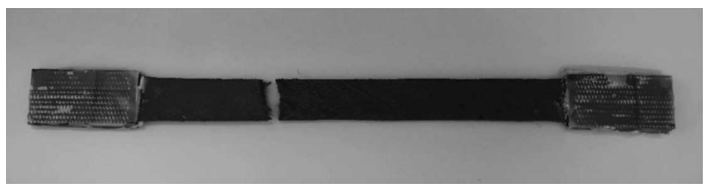

Fig. 16 Typical fractured $\pm 45^{\circ}$ specimen.

引張試験片には䋊維束の折り返しを取り除く方が良いと 判断される.

\section{$4.3 \pm 45^{\circ}$ 引張試験}

$\pm 45^{\circ}$ 引張試験の結果を Fig. 15 に示す. 横軸は JIS K7019 亿従って計算したせん断ひずみであり, 縦軸はせ 几断応力である.また, 破断試験片の様相を Fig. 16 亿示 す。通常の $\pm 45^{\circ}$ 引張試験片と同様に，3D プリント複合 材の $\pm 45^{\circ}$ 引張試験片も大きな非線形性を有している. $\pm 45^{\circ}$ 引張試験から得られたせん断剛性とせん断強度を Table 1 に示す.

この $\pm 45^{\circ}$ 引張試験においても，90引張試験と同じよ うに繊維束の折り返しが含まれる試験片で引張試験が実 施できる.この結果を Fig. 17 に示す. せん断弾性係数は $2.11 \mathrm{GPa}$ であり, せん断強度は $52.4 \mathrm{MPa}$ であった。 $\pm 45^{\circ}$ 引張試験では， $90^{\circ}$ 引張試験とは逆に，折り返しが あることで強度が低下している。なお，ひずみゲージの 測定可能な限界に達したために応力ーひずみ線図（Fig. 15）ではひずみ $5 \%$ までしか表示していない.

ひずみゲージ破断後は荷重のみ測定し，破壊時の最大 応力が $90 \mathrm{MPa}$ (治具間変位が $50 \mathrm{~mm}$ 程度) であること を実験的に確認している.これを Fig. 18 に示す. Fig. 18 の横軸は試験機の変位，縦軸はせん断応力である．Fig． 18 からわかるように, 折り返しが無い試験片では変位が $1 \mathrm{~mm}$ 程度から剛性が増加している。これは, せん断変形 で緘維の角度が $44^{\circ}$ から回転して角度が減少している ことを意味している.したがって, Table 1 に示したせん 断強度は正しくない.実際の伸びは繊維の回転と樹脂の

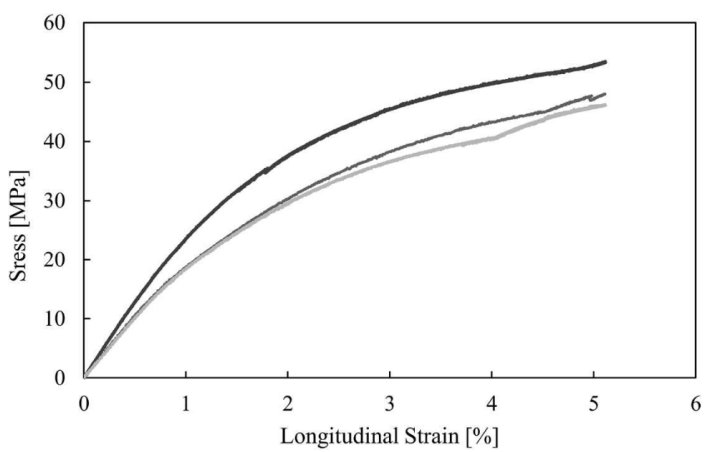

Fig. 17 Stress ${ }^{-}$strain curve of $\pm 45^{\circ}$ specimen with folded fiber bundles.

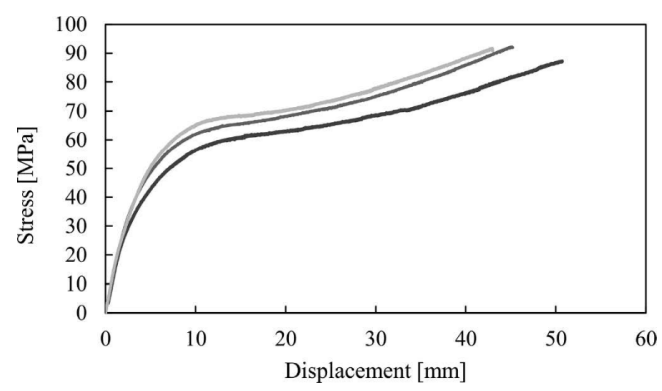

Fig. 18 Stress-displacement curve of $\pm 45^{\circ}$ specimen without folded fiber bundles.

塑性変形の両方を含むために評価できないが, $90.4 \mathrm{MPa}$ より少ないと思われる。

Fig. 18 において変位 $10 \mathrm{~mm}$ 程度で一端応力が平坦に なっている. 䋊維の回転と樹脂の塑性伸びが無い場合に は, このせん断応力程度の值で塑性せん断ひずみが増加 していくと推察されるが, 詳細は樹脂の塑性変形を含め た解析が必要であり, 今後の課題である.

$90^{\circ}$ 引張試験片と $\pm 45^{\circ}$ 引張試験片の繊維の折り返し 部分を比較した拡大写真を Fig. 19 に示す. Fig. 19 は実 際の破断した試験片の健全部の端部樹脂でレーザー彫刻 機（30 W 炭酸ガスレーザ彫刻機 HAJIME，Oh-laser) を用いて樹脂を焼失させて撮影した結果である. 繊維破 断が認められるが，これはレーザーに起因する結果なの か, 繊維束折り返しの結果なのか不明である. 重要な違 いは，90試験片では繊維束折り返しがほぼ $180^{\circ}$ の角度 でなされているが， $\pm 45^{\circ}$ 試験片では小さなループを作 っていることである. このループ内に樹脂が充填されて おらず，欠陥となっていることが 1 層だけ作製した試験 片で確認されている.同じ䋊維折り返しでも，このよう に異なる原因はスライスソフトのノズル軌道の差異に起 


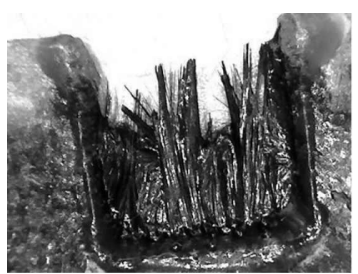

(a) 90-degree specimen

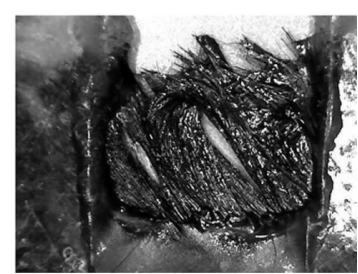

(b) \pm 45 -degree specimen
Fig. 19 Zoomed edge of $90^{\circ}$ and $\pm 45^{\circ}$ specimen at the folded fiber bundles.

因している，この差異が生じる原因はスライスソフトの アルゴリズムが不明であるためわからない.しかし，緎 維折り返しが纎維直線部と同じ強度を持たないという点 は重要であり, 今後の課題である.

以上から， $\pm 45^{\circ}$ 引張試験はせん断弾性係数の測定に は利用できるが，繊維の体積含有率の少ない熱可塑性樹 脂を用いた $3 \mathrm{D}$ プリント複合材のせん断強度測定には適 していないと思われる。

\section{4 積層方向試験}

積層方向引張試験の応力ーひずみ関係を Fig. 20 に示 す．積層方向の試験はばらつきが大きく，ほぼ線形の関 係で破断する低強度の試験片と, 非線形変形の後に破断 する高強度の試験片が存在している，積層方向引張試験 から得られた積層方向強度を Table 1 に示す。強度は $90^{\circ}$ 引張試験の $1 / 4$ 程度であり, 弾性係数も $90^{\circ}$ 引張試験 と比較して $40 \%$ ほど低下している. FDM 法では, 積層 の層間にボイドが発生しやすいが，この試験片では 800 層も積層しているために多くのボイドが存在しているこ とが原因であると考元られる。そこで，JIS K7075-1991 の燃焼法によってボイド率を測定した。 $0^{\circ}$ 引張試験片や $90^{\circ}$ 引張試験片では 7 8\%のボイド率であったが, 積層 方向引張試験片では $11.3 \%$ のボイド率となり, 層間が増 えるほどボイド率が上昇している。

実際の成形物に存在する層間のボイドは, 他の条件が 同一であるならば，ボイド率が一定となるだけである.

Fig. 21 亿試験片表面を $\pm 45^{\circ}$ 引張試験片と積層方向引張 試験片で比較して示す. $\pm 45^{\circ}$ 引張試験片では試験片表 面はノズルで押しつぶされて滑らかになるために, 表面 が平坦である.これに比較して, 積層方向引張試験片で は押しつぶされた纎維束を横から見る方向になるため, 凹凸が激しい。この凹凸によってボイド率の差異が生じ ていると思われる。また，この凹凸とボイドの確率的な 位置関係で低強度の断面から破壞していると思われる。

Fig. 22 に実際の CFRTP フィラメントの成形の模式

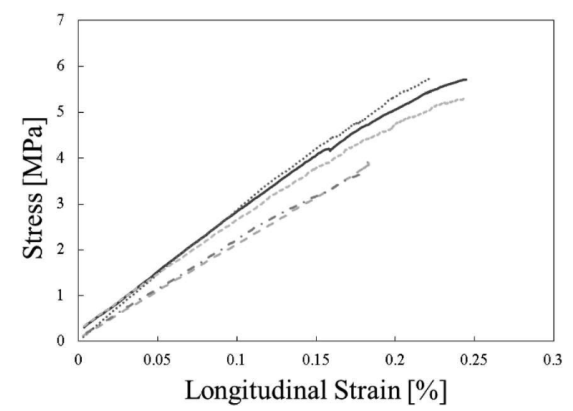

Fig. 20 Stress-strain curve of lay-up direction specimen.

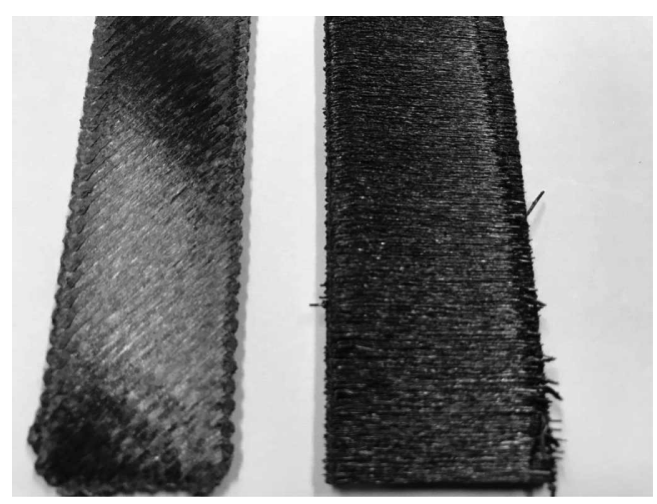

Fig. 21 Surface condition of $\pm 45^{\circ}$ specimen (left) and lay-up direction specimen (right).

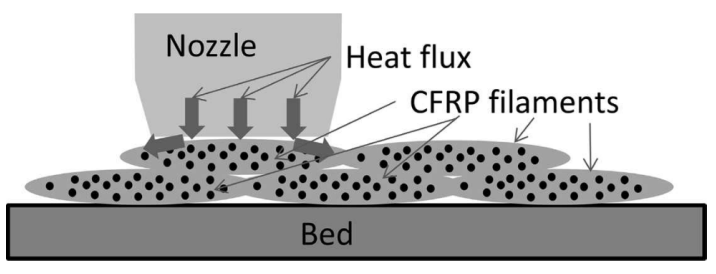

Fig. 22 Schematic model of heat flow during printing.

図を示す. 溶融したCFRTP フィラメントは，下および 横の既に存在するフィラメントを溶融させるために熱を 失う.CFRTPは,ノズルと接触しているため, 上部の高 温のノズルから熱を補給されている。このため, 押しつ ぶされて横に流動する樹脂は移動してきた熱を補給され ている.しかし,フィラメント下面は途中に瀻維があり, この繊維は紙面垂直方位に高い熱伝導率で熱を輸送す る.このため, 下面の樹脂にまで熱移動は発生しにくい. このために層間との融着が不良となる場合が多いものと 
思われる.この検証には融解熱や樹脂流動を含めた解析 が不可欠であり今後の課題である.

また，成形上の積層方向の位置精度の問題も考えられ る。積層方向に長い成形を行う場合, ベッドの平行度の 調整が完全でないために，少しずつ斜めに印刷される影 響が大きくなる.このため, 引張試験には曲げ負荷が加 わってしまうことも要因の一つである.

\section{5. 結 論}

本研究では実験が容易な引張試験に限定し, 様々な繊 維方位の引張試験片の成形を検討して, 機械的強度や弾 性係数を測定した. 得られた結果は以下の通りである.

(1) 繊維の折れ曲がり点の存在しない試験片では $0^{\circ} 引$ 張試験のばらつきは減少したが, 繊維束がたわむ影響 で引張負荷時に弾性係数が増加する場合がある.

（2） $90^{\circ}$ 引張試験では繊維の折れ曲がりが強度と剛性を 高くする.これを試験片から取り除くことで適切な引 張試験が実施できる.

（3） $\pm 45^{\circ}$ 引張試験では, 繊維の折れ曲がりはせん断強 度を低くする。これを取り除くと, 繊維の回転を伴う 大きな塑性変形を生じるため, せん断強度の測定がで きなくなる。

(4) 積層方向引張は $90^{\circ}$ 引張よりも弾性係数が $40 \%$ 減 少し,引張強度は $1 / 4$ に低下した。

本研究の遂行に当たり, NEDO「次世代構造部材創 製・加工技術開発」の研究開発項目(5)「航空機用構造設 計シミュレーション技術開発」, 研究テーマ名「低コス 卜機体開発を実現するための数值シミュレーション技術 開発 (航空機 CAE)」の支援を受けた. 関係各位に謝意 を表する。

\section{参 考 文 献}

1) K. Bell : The MarkOne Is World's First Carbon Fiber 3D Printer, 29 ${ }^{\text {th }}$ Jan, 2014, https://mashable. com/2014/01/29/carbon-fiber-3d-printer/\#4xTv2g YCEqV (Access 2019/3/11).

2) R. Matsuzaki, M. Ueda, M. Namiki, T.-K. Jeong, H. Asahara, K. Horiguchi, T. Nakamura, A. Todoroki \& Y. Hirano: Sci. Rep., 6 (2016), 23058. https://doi.org/10.1038/srep23058

3) Y. Koga \& A. Todoroki : Adv. Compos. Mater., https://doi.org/10.1080/09243046.2018.1470894

4) F. van der Klift, Y. Koga, A. Todoroki, M. Ueda, Y. Hirano \& R. Matsuzaki: Open J. Compos. Mater., 6, 1 (2016), 18-27. http://doi.org/10.4236/ ojcm.2016.61003

5) X. Tian, T. Liu, C. Yang, Q. Wang \& D. Li : Compos. Part A, 88 (2016), 198-205. https://doi. org/10.1016/j.compositesa.2016.05.032

6) G.W. Melenka, B.K.O. Cheung, J.S. Schofield, M. R. Dawson \& J.P. Carey: Compos. Struct., 153 (2016), 866-875. https://doi.org/10.1016/j.comp struct.2016.07.018

7) A.N. Dickson, J.N. Barry, K.A. McDonnell \& D.P. Dowling : Addit. Manuf., 16 (2017), 146-152. https:// doi.org/10.1016/j.addma.2017.06.004

8) J. Justo, L. Távara, L. García-Guzmán \& F. París : Compos. Struct., 185 (2018), 537-548. https://doi. org/10.1016/j.compstruct.2017.11.052

9) K. Ishii, A. Todoroki, Y. Mizutani, Y. Suzuki, Y. Koga, R. Matsuzaki, M. Ueda \& Y. Hirano : $A d v$. Compos. Mater., https://doi.org/10.1080/09243046. 2018.1558327

10) R. Matsuzaki, T. Nakamura, K. Sugiyama, M. Ueda, A. Todoroki, Y. Hirano \& Y. Yamagata : Addit. Manuf., 24 (2018), 93-102. https://doi.org/ 10.1016/j.addma.2018.09.019

11) https://markforged.com/materials/carbon-fiber/ (Access 2019/1/26) 